\title{
Vegetative Development and Nutrient Absorption March of Sorrel
} (Rumex acetosa L.)

\author{
Maria Angélica Suedan Souza Lima ${ }^{1}$, Anastácia Fontanetti ${ }^{1}$, Márcio Roberto Soares ${ }^{2}$, Rodrigo Gazaffi ${ }^{3}$, \\ Nathalia de França Guimarães ${ }^{4} \&$ Anderson de Souza Gallo ${ }^{4}$ \\ ${ }^{1}$ Department of Rural Development, Federal University of São Carlos, Araras, Brazil \\ ${ }^{2}$ Department of Natural Resources and Environmental Protection, Federal University of São Carlos, Araras, \\ Brazil \\ ${ }^{3}$ Department of Biotechnology and Plant and Animal Production, Federal University of São Carlos, Araras, \\ Brazil \\ ${ }^{4}$ Department of Soils, Federal Rural University of Rio de Janeiro, Seropédica, Brazil \\ Correspondence: Anderson de Souza Gallo, Department of Soils, Federal Rural University of Rio de Janeiro, \\ BR-465, Km 7, Postal Code: 23890-000, Seropédica, RJ, Brazil. Tel: 55-21-969-025-134. E-mail: \\ andersondsgallo@hotmail.com
}

Received: December 9, 2018

Accepted: January 11, 2019 Online Published: March 15, 2019

doi:10.5539/jas.v11n4p262

URL: https://doi.org/10.5539/jas.v11n4p262

\begin{abstract}
Sorrel (Rumex acetosa L.) is an unconventional food plant. It is a perennial herbaceous plant that forms thickets. There are studies related to the accumulation of nutrients in sorrel, but there is no information on its absorption march and vegetative development. The objective of this study is to determine macronutrient absorption and biometric parameters of sorrel during 60 days after seedling transplantation (DAT) of seedlings. The experiment was completely randomized with eight treatments and four replications. It was conducted in a greenhouse. The treatments consisted of plant collection times, performed at 15, 20, 25, 30, 35, 40, 50 and 60 DAT. Plants' biometric parameters (leaf blade length, relative leaf area, and shoot fresh and dry matter) and macronutrient absorption march were evaluated. Biomass, leaf blade length and relative leaf area of sorrel plants increased over time and, more markedly, after 35 DAT. The maximum levels of macronutrients accumulated in sorrel shoots, in descending order, were $\mathrm{K}>\mathrm{N}>\mathrm{Ca}>\mathrm{Mg}>\mathrm{P}>\mathrm{S}$. There was no significant difference in $\mathrm{Ca}$ and $\mathrm{S}$ contents among collection times, that is, the absorption and accumulation of these nutrients by sorrel did not vary throughout the evaluation time.
\end{abstract}

Keywords: Rumex acetosa L., unconventional food plants, biometric parameters, plant nutrition

\section{Introduction}

The agroindustry and markets have neglected some plants. They are currently considered weeds or grasses (Viana et al., 2015). Their ecological importance and their economic and food potential are neglected. This is mainly due to the modernization of agriculture and globalization, as well as the life style of contemporary society (Kinupp \& Barros, 2004).

Such species, known as unconventional food plants (PANCs), have been kept and grown in small gardens, backyards and farms. According to Madeira and Kinupp (2016), the term PANC began to be disseminated in 2008 through the documentary "PANCs Project: food sovereignty and palpable biodiversity", and the definition also includes food plants of non-organized productive chains. The recovery and valuing of such plants in food represent extraordinary gains. Traditionally, they are present in typical regional dishes relevant to cultural expression (Pedrosa et al., 2012). Encouraged mainly by rural tourism, these dishes have been rescued and reinvented, which has fostered the market of these dishes.

Sorrel (Rumex acetosa L.) is a perennial herbaceous plant of the family Polygonaceae. It reaches $25-55 \mathrm{~cm}$ in height and forms thickets with dozens of propagules (Kinupp \& Lorenzi, 2014). It has a low nutritional requirement and adapts to medium to low fertility soils (Gaweda, 2008). Sorrel is considered an unconventional food plant because it was at one time widely consumed by the population and, due to changes in dietary behavior, its economic and social expressions decreased, losing space and market for other vegetables (Pedrosa et al., 2012). 
This species occurs in wild regions of Europe, Asia and North America. In Brazil, it is cultivated in mild climate regions from Rio Grande do Sul to Minas Gerais (South-Southwest region). Its leaves can be consumed in natura or cooked. However, they present a high content of antinutricional factor, calcium oxalato, which limits the consumption by people with renal problems (MAPA, 2010). However, Redzic (2006) reported that this species has some therapeutic properties such as anti-scurvy, anti-diarrhea, anti-inflammatory and anticancer activity. It contains other substances, such as tannins, anthraquinones and flavonoids (Viana et al., 2015). The roots have an antioxidant activity and a mixture of polysaccharides revealed antitumor action in mice (Lee et al., 2005). Despite its importance, there is a lack of information on sorrel. Therefore, further studies on production, cultivation and nutritional properties are needed.

Knowledge on the nutrient absorption march, which is related to the plants' development stage, is of great importance for a rational fertilization strategy. Such knowledge avoids nutrient losses due to volatilization and leaching, and the possibility of contamination of water blade and watercourses. Such studies would allow understanding the moment when each element is more intensely absorbed, indicating the appropriate time for its supply (Fernandes et al., 1975). Absorption and nutrient requirements vary according to the plant's development stage. Nutrient requirements intensify at flowering and fruiting (Kano et al., 2011). In relation to sorrel, there are studies on nutrient accumulation (Silva et al., 2013; Torres, 2014; Viana et al., 2015; Silva et al., 2018). However, there is no information on the absorption march.

Thus, the objective of this study is to determine macronutrient absorption and biometric parameters of sorrel during 60 days after transplantation (DAT) of seedlings grown from seeds.

\section{Method}

The experiment was conducted in a greenhouse at the Agricultural Sciences Center of the Federal University of São Carlos (UFSCar) in the municipality of Araras, SP $\left(22^{\circ} 18^{\prime} 00^{\prime \prime} \mathrm{S}, 47^{\circ} 23^{\prime} 03^{\prime \prime} \mathrm{W}, 611 \mathrm{~m}\right.$ altitude), from August to November 2014.

The substratum was Alic Red Latosol (Oxisol) with a clayey texture (LV) (EMBRAPA, 2013). After sieved, the soil was placed in polyethylene pots with a capacity of $4.5 \mathrm{dm}^{3}$. According to manuals of cultivation of unconventional vegetables (Silveira et al., 2010; Pedrosa et al., 2012), the recommended fertilization for sorrel cultivation should be similar to that used for lettuce. Lettuce fertilization was used as reference in this study. In March 2014 (180 days before transplantation of seedlings to pots), $5.7 \mathrm{~g}$ of dolomitic limestone (PRNT $=85 \%$ ) were added to each pot to raise base saturation to $70 \%$ according to the recommendation for lettuce (Raij et al., 1997). The soil chemical analysis for fertility purposes was performed after liming following methods described by Raij et al. (2001). The results are $\mathrm{pH}=5.2, \mathrm{P}($ resin $)=2.40 \mathrm{mg} \mathrm{dm}^{-3}, \mathrm{~K}=2.9 \mathrm{mmol}_{\mathrm{c}} \mathrm{dm}^{-3}, \mathrm{Ca}=27 \mathrm{mmol}_{\mathrm{c}} \mathrm{dm}^{-3}$, $\mathrm{Mg}=12 \mathrm{mmol}_{\mathrm{c}} \mathrm{dm}^{-3}, \mathrm{H}+\mathrm{Al}: 29 \mathrm{mmol}_{\mathrm{c}} \mathrm{dm}^{-3}$, base saturation: $41.4 \mathrm{mmol}_{\mathrm{c}} \mathrm{dm}^{-3}$, cation exchange capacity: 70.4 $\mathrm{mmol}_{\mathrm{c}} \mathrm{dm}^{-3}$, and SOM $=9.5 \mathrm{~g} \mathrm{~kg}^{-1}$.

Fifteen days before seedling transplanting, $175 \mathrm{~g}$ of tanned bovine manure $\left(70 \mathrm{t} \mathrm{ha}^{-1}\right)$ were incorporated into the soil of each pot. The results of chemical analysis of manure (Nogueira \& Souza, 2005) were (\% dry weight): $\mathrm{pH}=$ 7.7, $\mathrm{P}_{2} \mathrm{O}_{5}=0.30 \%, \mathrm{C}=9.3 \%, \mathrm{~N}=1.05 \%, \mathrm{~K}_{2} \mathrm{O}=1.75 \%, \mathrm{CaO}=0.60 \%, \mathrm{MgO}=0.34 \%, \mathrm{SO}_{4}=0.21 \%$, humidity $=$ $15.84 \%, \mathrm{OM}=16.03 \%, \mathrm{Cu}=11 \mathrm{ppm}, \mathrm{Fe}=2,404 \mathrm{ppm}, \mathrm{Mn}=84 \mathrm{ppm}$, and $\mathrm{Zn}=13 \mathrm{ppm}$.

In order to standardize the development of all sorrel seedlings, the planting was done using seeds rather than division of thickets, as this species is commonly propagated. By using division by thickets, there is hardly any standardization in the development of seedlings due to a greater variability in the energy reserve of each propagule. Seeds, obtained from Botanical Interests, Inc. (lot \# 3), were sown in 128-cell expanded polystyrene trays using commercial substrate for the production of vegetable seedlings. After five days, seedlings emerged. The results of the chemical analysis of the substrate (Nogueira \& Souza, 2005) were $\mathrm{pH}\left(\mathrm{CaCl}_{2}\right)=5.5$, presine $=102.0 \mathrm{mg} \mathrm{dm}^{-3}$, $\mathrm{OM}=175.0 \mathrm{~g} \mathrm{dm}^{-3}, \mathrm{~K}=7.7 \mathrm{mmol}_{\mathrm{c}} \mathrm{dm}^{-3}, \mathrm{Ca}=72.0 \mathrm{mmol}_{\mathrm{c}} \mathrm{dm}^{-3}, \mathrm{Mg}=24.0 \mathrm{mmol}_{\mathrm{c}} \mathrm{dm}^{-3}, \mathrm{H}+\mathrm{Al}=25.0 \mathrm{mmol}_{\mathrm{c}} \mathrm{dm}^{-3}$, $\mathrm{BS}=104.0 \mathrm{mmol}_{\mathrm{c}} \mathrm{dm}^{-3}$, total CEC $=129.0 \mathrm{mmol}_{\mathrm{c}} \mathrm{dm}^{-3}$, and $\mathrm{V} \%=81$.

In September 2014, twenty-five days after plant emergence in trays, the seedlings were transplanted to the pots. Each pot received one plant. At that time, planting fertilization was carried out following the recommendation for lettuce (Raij et al., 1997): $0.5 \mathrm{~g}$ of ammonium sulphate per pot $\left(40 \mathrm{~kg} \mathrm{ha}^{-1}\right.$ of $\left.\mathrm{N}\right), 5.6 \mathrm{~g}$ of simple superphosphate per pot $\left(400 \mathrm{~kg} \mathrm{ha}^{-1}\right.$ of $\left.\mathrm{P}_{2} \mathrm{O}_{5}\right)$, and $0.4 \mathrm{~g}$ of potassium chloride per pot $\left(100 \mathrm{~kg} \mathrm{ha}^{-1}\right.$ of $\left.\mathrm{K}_{2} \mathrm{O}\right)$. Cover fertilizations were carried out at 10, 20 and 30 days after transplantation by applying $0.30 \mathrm{~g}$ of ammonium sulfate $\left(75 \mathrm{~kg} \mathrm{ha}^{-1} \mathrm{of}\right.$ $\mathrm{N})$ per pot at a time. After seedling transplantation, the pots were kept at a humidity of $70 \%$ of field capacity, verified daily by weighing. 
The experimental design was completely randomized with eight treatments and four replicates. Each plot contained three pots. The treatments consisted of plant collection times performed at 15, 20, 25, 30, 35, 40, 50 and 60 days after transplantation (DAT). The final collection was performed 60 days after transplantation, totaling 90 days between sowing and the last collection. This criterion was used because this plant seldom blooms in Brazilian climatic conditions (Silveira et al., 2010) and also because leaves show a greater palatability when they reach a length between 10 and $20 \mathrm{~cm}$, probably because they are not very fibrous (Pedrosa et al., 2012). In commercial crops, this plant is grown in thickets (perennials), but commercialized leaves are the youngest, with a size between 10 and $20 \mathrm{~cm}$.

At the time of collections, the whole plants were harvested, and later sectioned at the time of collection. The length of the four largest leaves of each plant was determined. Thus, the average for each plot was obtained. A ruler was used to measure the distance from the base to the apex. The area of the four largest leaves of each plant was also determined using a LICOR leaf area integrator (model LI-3000C). The results were presented as relative leaf area (total leaf area/number of leaves evaluated).

Afterwards, the plants were washed in deionized water and weighed to determine fresh matter. Then, they were placed in a forced air circulation oven at $65^{\circ} \mathrm{C}$ until reaching a constant mass. The fresh and dry matter values were determined in a semi-analytical balance with an accuracy of $0.01 \mathrm{~g}$. The accumulation of shoot fresh and dry matter was determined considering petiole + leaf in each collection time. The results were expressed in g plant $^{-1}$. After drying, the plants were processed using a Willey mill. The ground samples were analyzed to determine macronutrient contents (N, P, K, Ca, Mg and S) according to the method proposed by Nogueira and Souza (2005).

The results were submitted to analysis of variance and regression analysis using the SISVAR software for Windows (Ferreira, 2011). Significant equations were fitted to $1 \%$ and $5 \%$ probability, according to the $\mathrm{T}$ test, following the highest $\mathrm{R}^{2}$ coefficients.

\section{Results and Discussion}

The analyses of variance indicated that collection times (treatments) significantly influenced the biometric parameters and the absorption of macronutrients by sorrel, except for $\mathrm{Ca}$ and $\mathrm{S}$.

Normally, vegetables' dry matter and nutrient accumulation curves are fitted by polynomial models, which indicate a first phase of slow nutrient absorption followed by an intense absorption. At this phase, the maximum absorption point is identified. Later, absorption decreases. The biometric parameters (dry matter, fresh matter and leaf area) presented a cubic polynomial fitting in relation to harvesting times. The coefficients were higher than 0.98 and significant at $1 \%$ according to the T test (Figure 1). The highest accumulation of biomass occurred at 53 days after transplanting (DAT). On this day, there was the maximum production of fresh matter (Figure 1) and dry matter (Figure 2): 69.96 and $4.85 \mathrm{~g} \mathrm{plant}^{-1}$, respectively.

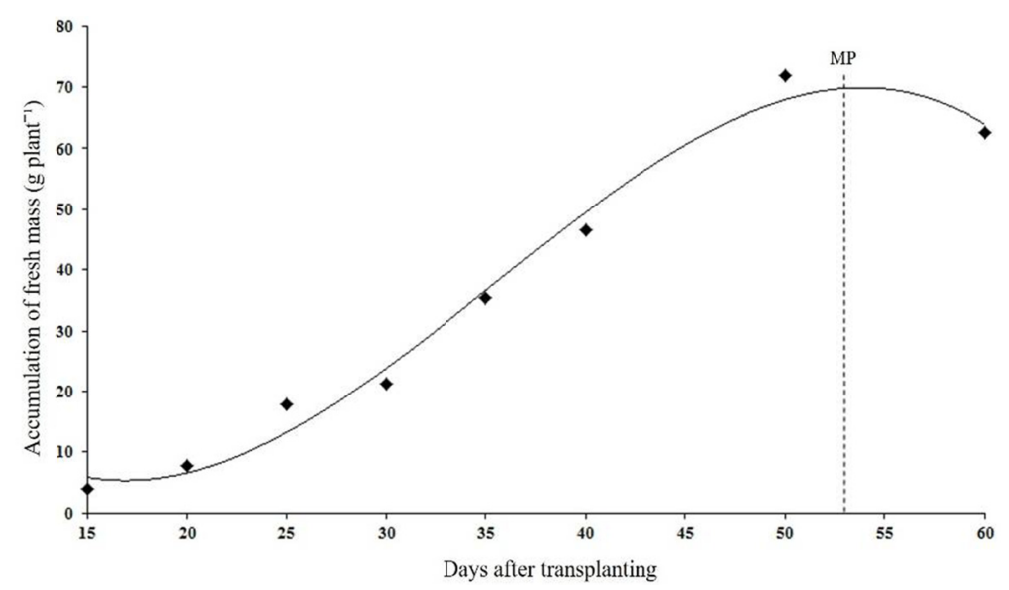

Figure 1. Accumulation of fresh matter by sorrel in function of days after transplantation. Araras, SP, Brazil, 2014. $\mathrm{MP}=$ maximum point of nutrient absorption

In the literature used as a reference (Pedrosa et al., 2012), the harvest of sorrel is carried out based on leaf size, which should be between 10 and $20 \mathrm{~cm}$ in length. According to the authors, leaves have a better palatability with that length, probably because they are less fibrous. Based on measurements of leaves of plants collected (Figure 3), 
the estimated range for the commercial harvest of sorrel seedlings from seeds would be between 20 and 35 DAT, when leaves had on average 10.2-20.13 cm in length, respectively. The plants should be between 45 and 60 days (accounting for the seedling production time from seeds and the time elapsed after transplantation).

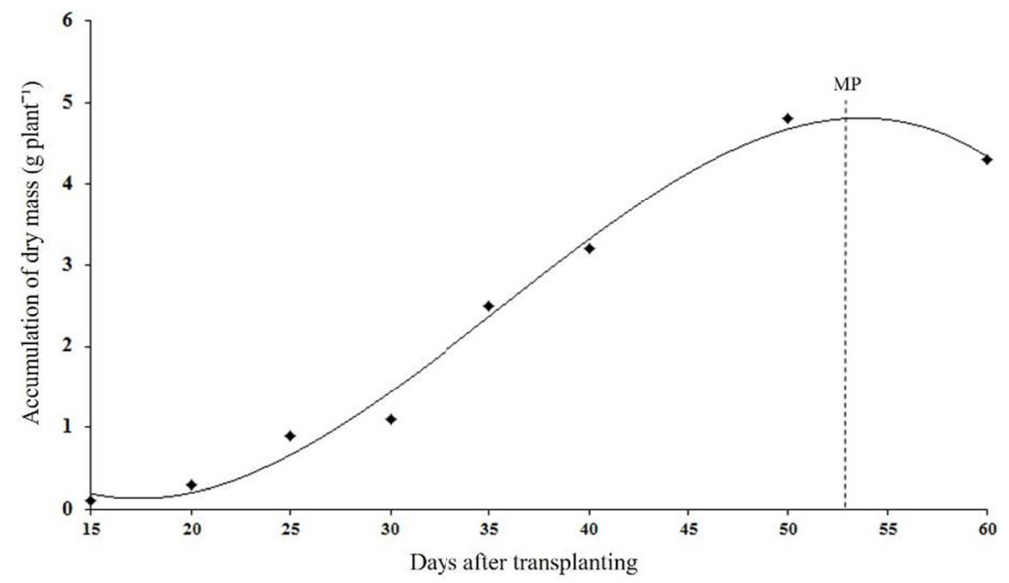

Figure 2. Accumulation of dry matter by sorrel in function of days after transplantation. Araras, SP, Brazil, 2014. $\mathrm{MP}=$ maximum point of nutrient absorption

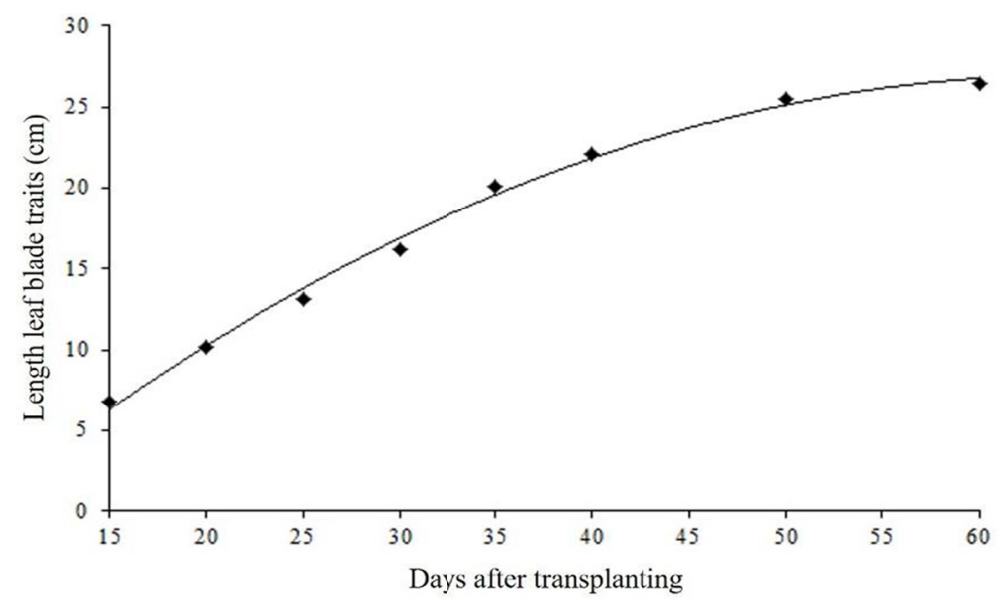

Figure 3. Leaf blade length of sorrel in function of days after transplantation. Araras, SP, Brazil, 2014

Therefore, in the estimated harvest interval, the shoot fresh matter ranged, on average, from $6.58 \mathrm{~g} \mathrm{plant}^{-1}$ (20 DAT) to $36.65 \mathrm{~g} \mathrm{plant}^{-1}$ (35 DAT) (Figure 1). The dry matter ranged, on average, from $0.22 \mathrm{~g} \mathrm{plant}^{-1}$ (20 DAT) to $2.39 \mathrm{~g}$ plant $^{-1}$ (35 DAT) (Figure 2). Between the estimated harvest interval and the maximum biomass accumulation of sorrel (53 DAT), fresh and dry matter increased significantly, that is, plants had the greatest increase in biomass after the period recommended for the commercial harvest of this species.

Proportionally to dry matter production, the relative leaf area of sorrel plants also increased, reaching the highest average at 55 DAT: $145.6 \mathrm{~cm}^{2}$ (Figure 4). By studying chicory cultivars, Novo et al. (2003) also verified that leaf area increased over time. According to Purquerioet al. (2007), the increase in leaf area or in photosynthetic canopy promotes a better use of solar energy for the generation of photoassimilates and, consequently, for the generation of dry matter. 


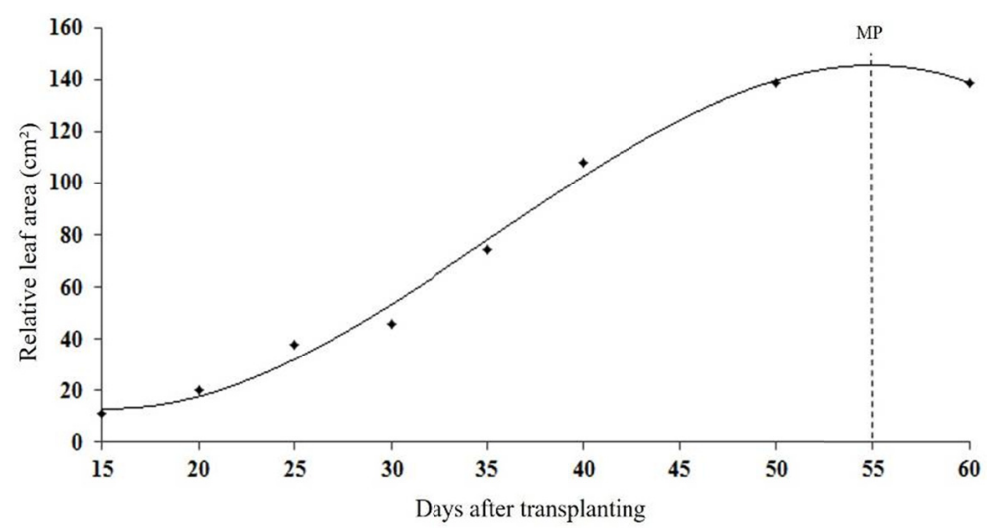

Figure 4. Relative leaf area of sorrel in function of days after transplantation. Araras, SP, Brazil, 2014. MP = maximum point of nutrient absorption

Since the initial stages of sorrel development, $\mathrm{K}$ was the most absorbed nutrient, with a mean content of $32.98 \mathrm{~g}$ $\mathrm{kg}^{-1}$ as early as 15 DAT (Figure 5). From 15 to 60 DAT, sorrel plants absorbed quantities of K between 30 and $60 \mathrm{~g}$ $\mathrm{kg}^{-1}$, with the maximum absorption $\left(58.22 \mathrm{~g} \mathrm{~kg}^{-1}\right)$ at 46 DAT. In the estimated range for sorrel commercial harvest (20 to $35 \mathrm{DAT}$ ), the $\mathrm{K}$ content observed was 31.74 and $48.74 \mathrm{~g} \mathrm{~kg}^{-1}$, respectively.

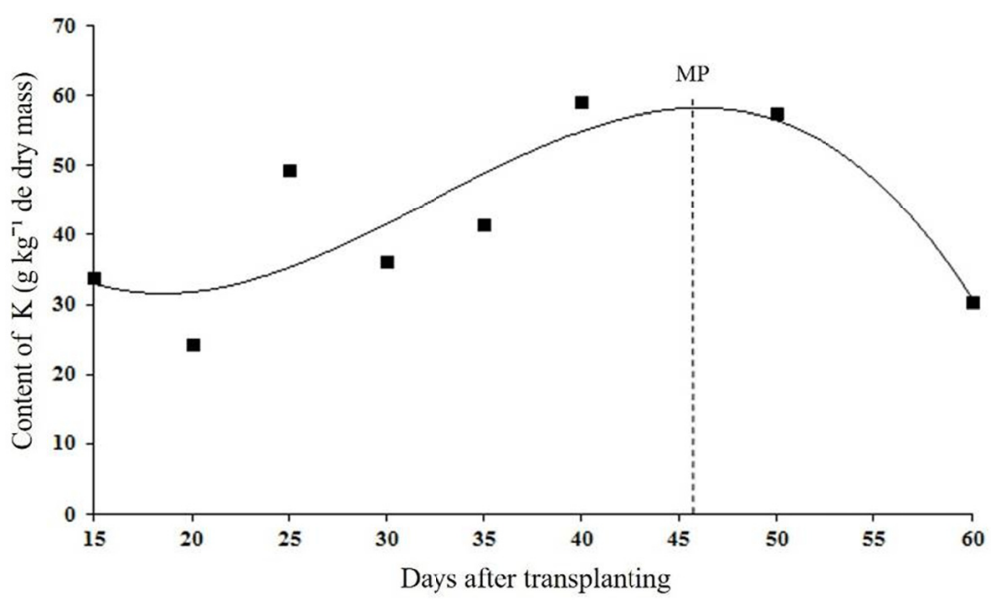

Figure 5. K content in the dry matter of sorrel in function of days after transplantation. Araras, SP, Brazil, 2014. MP $=$ maximum point of nutrient absorption

The maximum $\mathrm{K}$ content found in this work is within the ideal range of leaf $\mathrm{K}$ content for lettuce, which is $50-80 \mathrm{~g}$ $\mathrm{kg}^{-1}$ (Raijet al., 1997). Silva et al. (2013) and Torres (2014) also observed that K was the most absorbed nutrient by sorrel, reaching $40.2 \mathrm{~g} \mathrm{~kg}^{-1}$ (at the end of 90 days, Silva et al.) and $46.21 \mathrm{~kg} \mathrm{ha}^{-1}$ (at the end of 57 days, Torres). It is important to note that both Silva et al. (2013) and Torres (2014) cultivated plants from thickets and transplanted the seedlings to beds, which may justify some of the discrepancies between the results presented by this study.

$\mathrm{K}$ was also the macronutrient found at the highest concentration in the dry matter of other leafy vegetables, such as lettuce and coriander (Grangeiro et al., 2006; Kano et al., 2011). According to Ernani et al. (2007), the K content in leaves is a consequence of the availability of the nutrient in the soil, of absorption conditions by roots and of its translocation to shoots. This element is not part of any abiotic organic fraction of the soil and does not integrate any stable organic compound. Its contents in the soil organic matter are extremely low.

$\mathrm{N}$ was the second most absorbed nutrient by sorrel plants at 60 DAT. The behavior was explained by cubic polynomial fitting $\left(\mathrm{R}^{2}=0.80\right)$ (Table 1$)$. 
Table 1. Regression equations for nutrient absorption by sorrel. Araras, SP, Brazil, 2014

\begin{tabular}{llll}
\hline Nutrients & Regression equations & $\mathbf{R}^{2}$ & M.A. \\
\hline $\mathbf{N}$ & $\mathrm{Y}=-111.373492+10.298596 \mathrm{x}-0.214136 \mathrm{x}^{2}+0.001370 \mathrm{x}^{3}$ & $\mathrm{R}^{2}=0.80^{* *}$ & $45.94 \mathrm{~g} \mathrm{~kg}^{-1}$ \\
$\mathbf{P}$ & $\mathrm{Y}=2.720982-0.058812 \mathrm{x}+0.009212 \mathrm{x}^{2}-0.000143 \mathrm{x}^{3}$ & $\mathrm{R}^{2}=0.64 * *$ & $5.95 \mathrm{~g} \mathrm{~kg}^{-1}$ \\
$\mathbf{K}$ & $\mathrm{Y}=84.339801-6.574492 \mathrm{x}+0.248524 \mathrm{x}^{2}-0.002564 \mathrm{x}^{3}$ & $\mathrm{R}^{2}=0.68^{*}$ & $58.22 \mathrm{~g} \mathrm{~kg}^{-1}$ \\
$\mathbf{M g}$ & $\mathrm{Y}=-2373.966282+238.924921 \mathrm{x}-6.216405 \mathrm{x}^{2}+0.049851 \mathrm{x}^{3}$ & $\mathrm{R}^{2}=0.85^{* *}$ & $7.09 \mathrm{~g} \mathrm{~kg}^{-1}$ \\
\hline
\end{tabular}

Note. M. A. = Maximum nutrient accumulation; ${ }^{* *}$ significant according to Tukey test at $1 \%$ of probability;

*significant according to Tukey test at $5 \%$ of probability.

In the estimated range for commercial harvest (20-35 DAT), sorrel plants absorbed $\mathrm{N}$ amounts ranging from 19.9 to $45.5 \mathrm{~g} \mathrm{~kg}^{-1}$. The maximum $\mathrm{N}$ content in plant shoots was $45.94 \mathrm{~g} \mathrm{~kg}^{-1}$ at 37 DAT (Figure 6), i.e., close to the range estimated for commercial harvesting. This was probably due to the $\mathrm{N}$ uptake provided to plants by the cover fertilization performed at 30 DAT. The absorbed $\mathrm{N}$ contents remained constant until 40 DAT, decreasing to between 30 and $40 \mathrm{~g} \mathrm{~kg}^{-1}$ from 50 DAT.

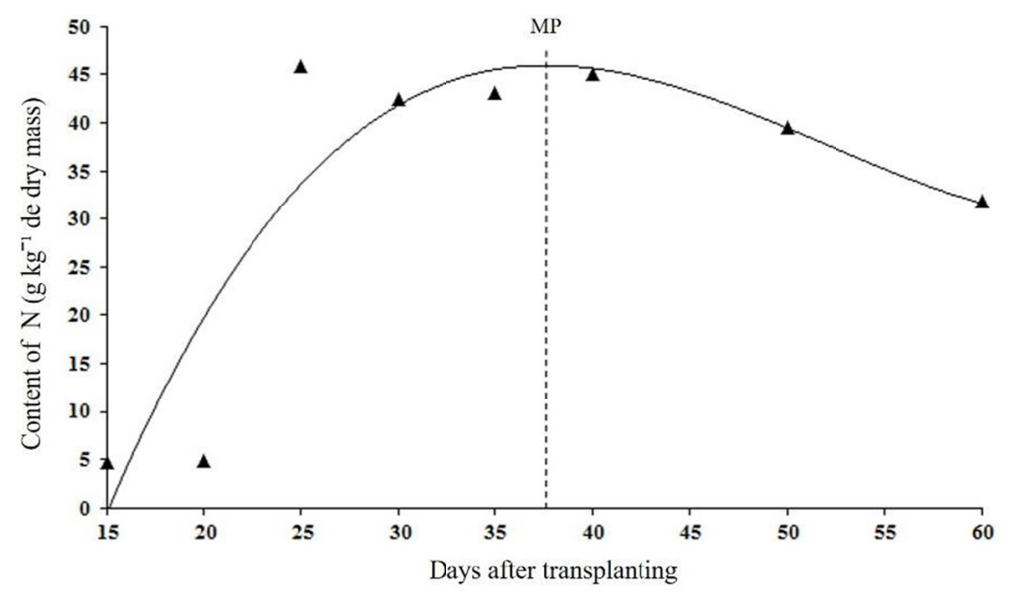

Figure 6. N content in the dry matter of sorrel in function of days after transplantation. Araras, SP, Brail, 2014. MP = maximum point of nutrient absorption

Silva et al. (2013) found that the $\mathrm{N}$ content in leaves was $26.2 \mathrm{~g} \mathrm{~kg}^{-1}$ after 90 days of sorrel cultivation. For lettuce, the maximum $\mathrm{N}$ content found in this work is within the ideal range of leaf $\mathrm{N}$ content, which is $30-50 \mathrm{~g} \mathrm{~kg}^{-1}$ (Raijet al., 1997). According to Grangeiro et al. (2011), there is a direct relation between $\mathrm{N}$ absorption and the increase of dry matter throughout the lettuce crop cycle. Since sorrel is basically composed of leaves, it responds well to the nitrogen supply since this mineral is absorbed by roots and assimilated to meet the nitrogenous needs of the plant. There is a link between $\mathrm{N}$ absorption and dry matter increase on the crop cycle scale. Between 20 and 35 DAT, sorrel plants had the highest biomass yield, with a 5.6 times increase. Therefore, it is probable that the cover fertilization carried out between the 20 and 30 DAT favored the growth of sorrel, coinciding with the range proposed for commercial harvests.

The macronutrients $\mathrm{P}$ and $\mathrm{Mg}$ presented lower accumulation rates in shoots of sorrel plants. The contents of $\mathrm{P}$ and $\mathrm{Mg}$ in the plant tissue were below $15 \mathrm{~g} \mathrm{~kg}^{-1}$ (Figures 7 and 8). After cubic polynomial fitting, with a $\mathrm{R}^{2}$ of 0.64 (Figure 7 and Table 1), it was possible to identify a maximum content of $5.95 \mathrm{~g} \mathrm{~kg}^{-1}$ of $\mathrm{P}$ at 39 DAT. Among the estimated ranges for the commercial harvest (20-35 DAT), a variation in contents between 4.08 and $5.81 \mathrm{~g} \mathrm{~kg}^{-1}$, respectively, was recorded. Subsequently, there was a drastic reduction in $P$ content, reaching $1.46 \mathrm{~g} \mathrm{~kg}^{-1}$ (Figure 7), that is, below that observed by Silva et al. (2013) after 90 days of cultivation, when plants presented $5.1 \mathrm{~g} \mathrm{~kg}^{-1} \mathrm{of} \mathrm{P}^{\mathrm{P}}$ in their leaves. 


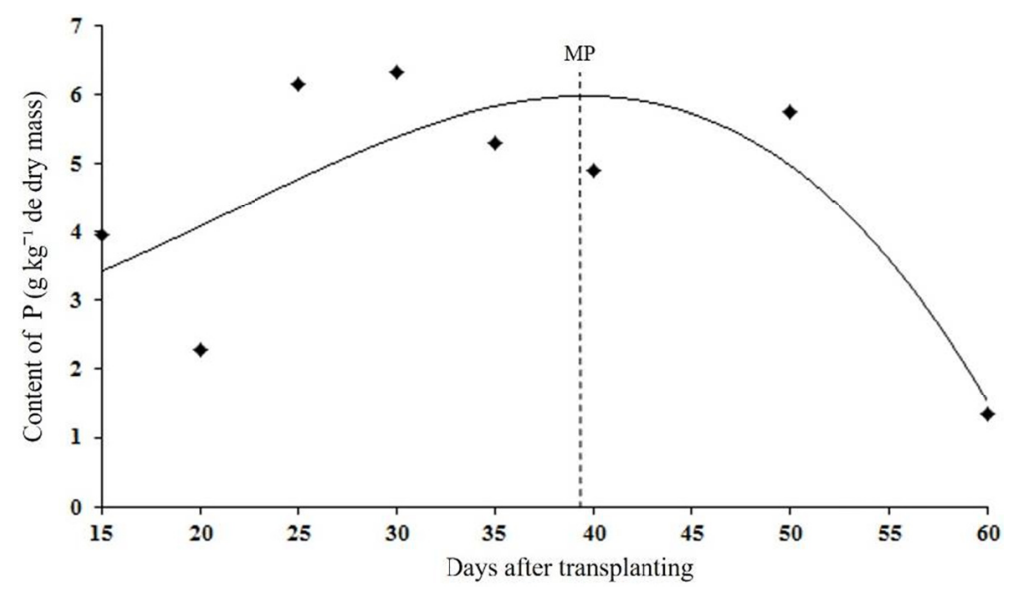

Figure 7. P content in the dry matter of sorrel in function of days after transplantation. Araras, SP, Brazil, 2014. MP $=$ maximum point of nutrient absorption

The maximum $P$ content in this study was higher than the range considered ideal for lettuce, which is $4-7 \mathrm{~g} \mathrm{~kg}^{-1}$ (Raijet al., 1997). It is noteworthy that the soil used in this work, LV, presents a high P adsorption potential. This element, initially adsorbed to the surface of aggregates, diffuses over time to the interior. This process is responsible for reducing the availability of $P$ in a recently fertilized soil (Novais et al., 2007).

Regarding Mg, plants accumulated the maximum content at 50 DAT, with a value of $7.09 \mathrm{~g} \mathrm{~kg}^{-1}$ (Figure 8). Between the estimated ranges for the commercial harvest (20-35 DAT), a variation in contents between $3.39 \mathrm{~g} \mathrm{~kg}^{-1}$ (20 DAT) and $5.51 \mathrm{~g} \mathrm{~kg}^{-1}$ (35 DAT) was recorded. Mg contents increased up to 50 DAT, and from 60 DAT they decreased, reaching a value of $5.9 \mathrm{~g} \mathrm{~kg}^{-1}$. This value is close to that found by Silva et al. (2013) at the end of 90 days of sorrel cultivation $\left(5.5 \mathrm{~g} \mathrm{~kg}^{-1}\right)$. The maximum $\mathrm{Mg}$ content found in this work is above the ideal range for lettuce, which is 4-6 $\mathrm{g} \mathrm{kg}^{-1}$ (Raijet al., 1997).

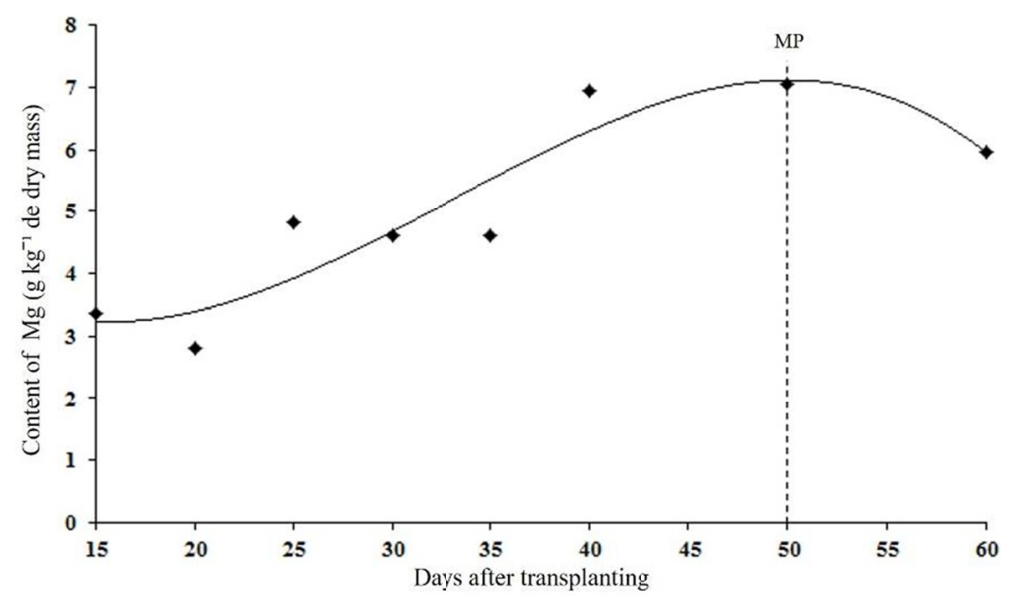

Figure 8. Mg content in the dry matter of sorrel in function of days after transplantation. Araras, SP, Brazil, 2014. $\mathrm{MP}=$ maximum point of nutrient absorption

There was no significant difference in $\mathrm{Ca}$ and $\mathrm{S}$ contents among collection times, that is, the absorption and accumulation of these nutrients by sorrel did not vary throughout the evaluation time. The mean $\mathrm{Ca}$ and $\mathrm{S}$ contents in sorrel shoots were 10.1 and $3.9 \mathrm{~g} \mathrm{~kg}^{-1}$. Such values were higher than the contents of $6.1 \mathrm{~g} \mathrm{~kg}^{-1}$ of Ca and $2.0 \mathrm{~g}$ $\mathrm{kg}^{-1}$ of S reported by Silva et al. (2013) at the end of 90 days of sorrel cultivation. The Ca presented contents below the ideal leaf content range for lettuce, which is $15-25 \mathrm{~g} \mathrm{~kg}^{-1}$ (Raijet al., 1997). The S, however, had an accumulation value higher than the ideal range, which is $1.5-2.5 \mathrm{~g} \mathrm{~kg}^{-1}$ (Raijet al., 1997). The absorption of Ca (divalent cation) is influenced by the presence of the antagonistic ions $\mathrm{K}^{+}$and $\mathrm{NH}_{4}{ }^{+}$. These ions reduce $\mathrm{Ca}$ 
absorption (Marenco \& Lopes, 2009). It may explain the small variation in the absorption of Ca by sorrel plants over time.

The maximum levels of macronutrients accumulated in sorrel shoots, in descending order and in $\mathrm{g} \mathrm{kg}^{-1}$, were $58.22(\mathrm{~K})>45.94(\mathrm{~N})>10.1(\mathrm{Ca})>7.09(\mathrm{Mg})>5.95(\mathrm{P})>3.9(\mathrm{~S})$. The result is similar to that obtained by Silva et al. (2013) and Torres (2014) in their studies on sorrel. However, these results differed from the decreasing order of macronutrients accumulated in different lettuce cultivars obtained by Granjeiro et al. (2006), which was $\mathrm{K}>\mathrm{N}>\mathrm{P}>\mathrm{Mg}>\mathrm{Ca}$.

The use of nutrient content curves as a parameter for fertilization recommendation is a good indication of the nutrient needs at each stage of plant development. The amounts absorbed were optimal to achieve a certain productivity, thus helping to establish a fertilization for the crop and mainly facilitating the fractionation of fertilization. However, they should not be used in isolation since other factors are involved and should be taken into account, such as soil type, climatic conditions, crop management and fertilizers (Grangeiro et al., 2006).

Concentrating a fertilizer that provides macronutrients at the beginning of transplantation of sorrel plants whose seedlings were obtained from seeds seems to be an efficient way to promote the best use of nutrients for plant development, especially before the estimated commercial harvest interval (between 20 and 35 DAT). A good strategy would be to increase the amount of $\mathrm{N}$ in planting fertilization and to perform only one cover fertilization at 15 DAT. The maximum biomass accumulation point did not occur within the estimated harvest interval. These results probably do not apply to seedlings obtained from seeds. Further studies on this topic are needed. According to Torres (2014), it is important to consider the amount of nutrients exported by the crop since it represents a constant and increasing loss of system elements because sorrel is a plant that re-sprouts and allows successive cuts.

\section{Conclusion}

Biomass and relative leaf area of sorrel plants increased over the days after transplanting and, more markedly, within the estimated commercial harvest time (20-35 DAT), when the leaves would have 10.2 and $20.13 \mathrm{~cm}$ in length, respectively.

The maximum absorption of $\mathrm{N}, \mathrm{P}, \mathrm{K}$ and $\mathrm{Mg}$ occurred after the estimated commercial harvest interval. The $\mathrm{Mg}$ absorption peaked near the maximum biomass accumulation point.

\section{Acknowledgements}

The authors thank the 'Conselho Nacional de Desenvolvimento Científico e Tecnológico' (CNPq) for granting a scholarship to the first author.

\section{References}

EMBRAPA (Empresa Brasileira de Pesquisa Agropecuária). (2013). Sistema brasileiro de classificação de solos (3rd ed., p. 353) Brasília: EMBRAPA.

Ernani, P. R., Almeida, J. A., \& Santos, F. C. (2007). Potássio. In R. F. Novais, V. V. H. Alvarez, N. F. Barros, R. L. F. Fontes, R. B. Cantarutti, \& J. C. L. Neves (Eds.), Fertilidade do Solo (pp. 551-594). Viçosa, MG: Sociedade Brasileira de Ciência do Solo.

Fernandes, P. D., Oliveira, G. D., \& Haag, H. P. (1975). Mineral nutrition of ornamental plants. VIII-absorption and deficiency of nutrients by Chrysanthemum morifolium L., cv. 'Suzuki'. Anais da Escola Superior de Agricultura Luiz de Queiroz, 32, 471-492. https://doi.org/10.1590/S0071-12761975000100040

Ferreira, D. F. (2011). Sisvar: A computer statistical analysis system. Ciência e Agrotecnologia, 35(6), 1039-1042. https://doi.org/10.1590/S1413-70542011000600001

Gaweda, M. (2008). Heavy metal content in common sorrel plants (Rumex acetosa L.) obtained from natural sites in Malopolska province. Polish Journal of Environmental Studies, 18(2), 213-218.

Grangeiro, L. C., Costa, K. R., Medeiros, M. A., Salviano, A. M., Negreiros, M. Z., Bezerra Neto, F., \& Oliveira, S. L. (2006). Accumulation of nutrients by three lettuce cultivars grown under Semi-arid conditions. Horticultura Brasileira, 24, 190-194. https://doi.org/10.1590/S0102-05362006000200013

Grangeiro, L. C., Oliveira, F. C. L., Negreiros, M. Z., Marrocos, Lucena, R. R. N., \& Oliveira, R. A. (2011). Nutrients growth and accumulation in coriander and rocket. Revista Brasileira de Ciências Agrárias, 6(1),

Kano, C., Cardoso, A. I. I., Villas Bôas, \& R. L. (2011). Nutrients uptake by lettuce plants for seed production. Horticultura Brasileira, 29, 70-77. https://doi.org/10.1590/S0102-05362011000100012 
Kinupp, V. F., \& Barros, I. B. I. (2004). Data survey and report of potentially alternative food plants in Brazil. Horticultura Brasileira, 22(2), 1-4.

Kinupp, V. F., \& Lorenzi, H. (2014). Plantas Alimentícias Não Convencionais (PANC) no Brasil: Guia de identificação, aspectos nutricionais e receitas ilustradas. São Paulo, SP: Instituto Plantarum de Estudos da Flora.

Lee, N. J., Choi J. H., Koo, B. S., Ryu, S. Y., Han, Y. H., Lee, S. I., \& Lee, D. U. (2005). Antimutagenicity and cytotoxicity of the constituents from the aerial parts of Rumex acetosa. Biological and Pharmaceutical Bulletin, 28, 2158-2161. https://doi.org/10.1248/bpb.28.2158

Madeira, N. R., \& Kinupp, F. V. (2016). Hortaliças não convencionais folhosas: Experiências com as plantas alimentícias não convencionais no Brasil. Informe Agropecuário, 37, 7-11.

MAPA (Ministério da Agricultura, Pecuária e Abastecimento). (2010). Manual de hortaliças não convencionais. Brasília, DF: Ministério da Agricultura, Pecuária e Abastecimento.

Marenco, R. A., \& Lopes, N. F. (2009). Fisiologia vegetal: Fotossíntese, respiração, relações hídricas e nutrição mineral. Viçosa, MG: Universidade Federal de Viçosa.

Nogueira, A. R. R., \& Souza, G. B. (2005). Manual de laboratórios: Solo, água, nutrição vegetal, nutrição animal e alimentos. São Carlos, SP: Embrapa Pecuária Sudeste.

Novais, R. F., Smyth, T. J., \& Nunes, F. N. (2007). Fósforo. In R. F. Novais, T. J. Smyth, \& F. N. Nunes (Eds.), Fertilidade do Solo (pp. 472-500). Viçosa, MG: Sociedade Brasileira de Ciência do Solo.

Novo, M. C. S. S., Trani, P. E., \& Minami, K. (2003). Performance of three chicory cultivars grown in greenhouse. Horticultura Brasileira, 21(1), 84-87. https://doi.org/10.1590/S0102-05362003000100018

Pedrosa, M. W., Mascarenhas, M. H. T., Magalhães, K. S., Silvério, T. T., Silva, A. F., Santos I. C., ... Bortolini, L. O. F. (2012). Hortaliças não convencionais. Belo Horizonte, MG: Epamig.

Purquerio, L. F. V., Derant, L. A. R., Goto, R., \& Villas Boas, R. L. (2007). Effect of side dressing nitrogen fertilization and distance between plants on yield of rocket salad. Horticultura Brasileira, 25(3), 464-470. https://doi.org/10.1590/S0102-05362007000300028

Raij, B. V., Andrade, J. C., Cantarella, H., \& Quaggio, J. A. (2001). Análise química para avaliação da fertilidade de solos tropicais. Campinas, SP: Instituto Agronômico/Fundação IAC.

Raij, B. V., Cantarella, H., Quaggio, J. A., \& Furlani, A. M. C. (1997). Recomendações de adubação e calagem para o Estado de São Paulo. Campinas, SP: Instituto Agronômico/Fundação IAC.

Redzic, S. J. (2006). Wild edible plants and their traditional use in the human nutrition in Bosnia-Herzegovina. Ecology of Food and Nutrition, 45, 189-232. https://doi.org/10.1080/03670240600648963

Silva, E. C., Carlos, L. A., Araújo, A. P., Ferraz, L. C. L., Pedrosa, M. W., \& Silva, L. S. (2013). Characterization of two types of azedinha in the region of Sete Lagoas, Brazil. Horticultura Brasileira, 31(2), 328-331.

Silva, L. F. L., Souza, D. C., Resende, L. V., Nassur, R. C., Samartini, M. R., \& Gonçalves, W. M. (2018). Nutritional Evaluation of Non-Conventional Vegetables in Brazil. Anais da Academia Brasileira de Ciências, 90(2), 1775-1787. https://doi.org/10.1590/0001-3765201820170509

Torres, M. P. (2014). Espaçamento e adubação orgânica na produção e no teor de compostos bioativos de azedinha-Rumex acetosa L (Dissertação de Mestrado, Universidade Federal de São João Del-Rei, São João Del-Rei, Brazil).

Viana, M. M. S., Carlos, L. A., Silva, E. C., Pereira, S. M. F., Oliveira, D. B., \& Assis, M. L. V. (2015). Phytochemical composition and antioxidant potential of unconventional vegetables. Horticultura Brasileira, 33(4), 504-509. https://doi.org/10.1590/S0102-053620150000400016

\section{Copyrights}

Copyright for this article is retained by the author(s), with first publication rights granted to the journal.

This is an open-access article distributed under the terms and conditions of the Creative Commons Attribution license (http://creativecommons.org/licenses/by/4.0/). 